\title{
Dakwah Dan Kekuasaan (Studi Dakwah Nabi Muhammad pada Periode Madinah)
}

\author{
Mastori \\ STAI PTDII Jakarta \\ Email : mastory87@gmail.com \\ A. Salman Maggalatung \\ UIN Syarif Hidayatullah Jakarta \\ Zenal Arifin \\ Institut Pembina Rohani Islam Jakarta
}

\begin{abstract}
The concept of the relationship between da'wah and power, especially what was practiced by the Prophet Mubammad in his da'wah in the Medina period, is an important object of research. This period was the starting point of the victory of da'wah which had enormous implications for the development of Islam in its end. The results showed that preaching and power in the Medina period had very strong relations. Most Islamic law cannot be implemented without a policy of authority. Power is inspired and exercised by the direction of revelation while preaching becomes strong and effective sustained by strength. Evidently the compilation of legalities possessed by the Prophet Muhammad was obtained through the process of Bai'at I and II in Medina, the development of Islam proceeded very quickly to reach the Arabian peninsula. The success of the Prophet Muhammad's leadership in Medina in integrating da'wah and power was important to make policy foothold by state officials.
\end{abstract}

Keywords: Da'wah, Power, Medina

\begin{abstract}
Abstrak
Konsep relasi dakwah dan kekuasaan, khususnya yang dipraktekan oleh Nabi Muhammad dalam dakwahnya pada periode Madinah penting menjadi objek penelitian. Periode ini merupakan titik tolak kemenangan dakwah yang memiliki implikasi yang sangat besar bagi perkembangan Islam pada masamasa sesudahnya. Hasil penelitian menunjukkan bahwa dakwah dan kekuasaan pada periode Madinah memiliki relasi atau hubungan yang sangat kuat. Bahkan syariat Islam sebagian tidak dapat diterapkan tanpa adanya kebijakan kekuasaan. Kekuasaan diilhami dan dijalankan dengan petunjuk wahyu sementara dakwah menjadi kuat dan efektif ketika ditopang oleh kekuasaan. Terbukti ketika legalitas kekuasaan telah Nabi Muhammad dapatkan melalui proses bai'at I dan II di Madinah, perkembangan Islam berproses sangat cepat hingga menguasai jazirah Arab. Keberhasilan kepemimpinan Nabi Muhammad di Madinah dalam menginetgrasikan dakwah dan kekuasaan penting untuk dijadikan pijakan kebijakan oleh para penyelenggara negara.
\end{abstract}

Kata kunci: Dakwah, Kekuasaan, Madinah 


\section{Pendahuluan}

Dakwah Islam memiliki kedudukan yang sangat penting dalam Islam, bahkan menjadi tujuan utama diutusnya para Nabi dan Rasul. Melalui kegiatan dakwah yang dilaksanakan oleh para Nabi, lahir perubahan-perubahan masyarakat dalam skala kecil maupun besar kearah yang lebih baik terutama perubahan dalam bidang pemikiran, pedoman dan orientasi hidup serta etika dan budaya.

Secara substansial, dakwah adalah perwujudan atas tuntutan iman yang diimplementasikan dalam berbagai aspek kehidupan manusia dengan melakukan proses perubahan atau rekayasa sosial melalui sentuhan rasa, pola pikir dan sikap agar seirama dengan tuntutan ajaran Islam. ${ }^{1}$ Proses perubahan sosial ini secara bertahap berhasil dilakukan oleh nabi Muhammad dalam waktu sekitar 23 tahun di Jazirah Arab.

Menurut Abudin Nata, risalah Islam yang diturunkan kepada Rasulullah ini didakwahkan melaui berbagai pendekatan diantaranya adalah melalui pendekatan tarbiyah atau pendidikan terhadap masyarakat Arab ketika itu. ${ }^{2}$ Pendekatan dakwah yang digunakan oleh Nabi dalam memenuhi kewajiban dakwah ini, umat Islam harus memperhatikan rambu-rambu Islam dan tidak menghalalkan segala cara yaitu dengan cara menjadikan Nabi Muhammad SAW sebagai rujukan atau suri teladan, baik metode, etika dan ushlubnya.

Perjalanan dakwah nabi Muhammad dalam menyebarkan Islam, seluruhnya wajib dijadikan sebagai suri teladan bagi generasi umat Islam sesudahnya terutama dalam membangun masyarakat Islam yang kuat sehingga mampu menciptakan situasi sosial, politik dan keamanan yang kondusif dan dapat memberikan perlindungan bagi segenap manusia yang hidup dalam naungan Islam. Dengan demikian, selain merupakan perintah Allah untuk meneladani Nabi Muhammad SAW, termasuk dalam merealisasikan kewajiban dakwah, beliau merupakan sosok teladan yang terbukti berhasil mewujudkan tatanan masyarakat Islam yang kuat.

Keberhasilan beliau dalam mengelola dakwah memberikan dampak yang luar biasa bagi kemanusiaan. Oleh karena itu, wajar bila Michael H. Hart dalam bukunya yang berjudul "Seratus Tokoh yang Paling Berpengaruh dalam Sejarab" meenempatkan Nabi Muhammad sebagai tokoh pertama yang paling berpengaruh bagi kehidupan umat manusia sepanjang masa dan mengalahkan tokoh-tokoh berpengaruh dunia lainnya. ${ }^{3}$

Pengaruh dakwah Nabi Muhammad terhadap terciptanya peradaban manusia yang tinggi tidak dapat dilepaskan dari peran beliau sebagai Kepala Negara di Madinah yang kemudian berhasil menancapkan pilar-pilar politik Islam. ${ }^{4}$ Pilar ini

1 Asep Saeful Muhtadi, Era baru Politik Mubamadyah, (Bandung, Penerbit Humaniora, 2005). 5

${ }^{2}$ Abudin Nata, Sejarah Pendidikan Islam pada Periode Klasik dan Pertengahan, Jakarta, PT Grafindo Persada, 2010). 204

${ }^{3}$ Michael H. Hart, Seratus Tokoh yang Paling Berpengaruh dalam Sejarah, (Jakarta, Pustaka Jaya, 1986). 28

4 Menurut Saidi, dalam Islam ilmu politik masuk dalam pembahasan fiqh siyasah yang merujuk kepada sumber-sumber hukum Islam yang baku yaitu kitab suci Al-Qur'an, Sunah atau segala yang bersumber dari Nabi baik perkataan, perbuataan maupun taqrir nabi, 
yang kemudian dijadikan sebagai acuan oleh generasi sesudahnya untuk menyebarkan Islam keseluruh pelosok dunia.

Dalam menjalankan aktivitas dakwah di Madinah, Nabi Muhammad memainkan peran yang berbeda dibanding dakwahnya di Mekah. Di Mekkah Nabi hanya berkutat pada pembinaan tauhid dan ajakan untuk memeluk agama Islam. Ajakan itu kadang diterima dan kadang ditolak. Penolakan tersebut kerap diiringi dengan cacian, hinaan bahkan siksaan. Menghadapi semua itu Nabi dan sahabat beliau menyikapinya dengan kesabaran dan tidak membalas perlakuan kasar mereka dengan kekerasan.

Kondisi demikian berbeda dengan karakter dakwah Nabi Muhammad di Madinah yang lebih berani, terbuka dan menjawab berbagai tantangan hingga sampai pada peperangan atau jihad fi sabilillah. Hal ini disebabkan di Madinah beliau telah memiliki kewenangan atau kekuasaan dalam mengimplementasikan risalah Islam yang beliau bawa. Dengan kecerdasan dan bimbingan wahyu yang beliau terima, kekuasaan yang ada dijalankan untuk menerapkan Islam dalam menghukumi masyarakat baru di Madinah yang beliau pimpin. ${ }^{5}$

Menurut Ahmad Usyairi, ada tiga alasan dakwah yang dibawa Nabi Muhammad mendapat sambutan yang positif sehingga diterima sebagai agama oleh penduduk Madinah, yaitu ;

Pertama, secara historis, penduduk Yatsrib/Madinah termasuk masyarakat yang memiliki hubungan dekat dengan agama samawi. Kedekatan itu membuat banyak penduduk Madinah yang mendengar dan berdekatan dengan orang- orang Yahudi perihal agama samawi itu.

Kedua, Orang-orang Arab di Madinah terbiasa mendengarkan kabar akan kedatangan Rasul akhir zaman dari lisan orang-orang Yahudi di Yastrib (Madinah). Sebab orang-orang Yahudi Yastrib kerap melontarkan ancaman kepada orang Arab Yastrib bahwa apabila telah datang Nabi akhir zaman maka mereka akan mengikuti nabi tersebut dan mengusir orang-orang Arab. Ancaman tersebut biasanya terlontar ketika Yahudi Yastrib berselisih dengan orang Arab. Tanpa disadari, orang-orang Arab Yastrib justru ikut menunggu-nunggu kabar kedatangan Nabi tersebut dan bertekad menjadi pengikutnya sebelum orang-orang Yahudi mengikuti.

Ketiga, sebelum Islam datang, permusuhan yang cukup keras melibatkan dua suku besar di Yastrib yaitu suku Aus dan Khazraj. Karena itu, mereka berlomba

kebijakan politik para khalifah pengganti Rasulullah yang dikenal dengan Khulafaur Rasyidin serta pembahasan Fiqh yang bersifat dinamis. Lihat Saidi Abu Jaib, Dirasat Fi Manhaj al Islami al Siyasi, (Beirut, Muassisah al-Risalah, 1985). 33

${ }^{5}$ Menurut Ali Mustofa Ya'kub, dakwah di Madinah berbeda dengan dakwah di Mekkah. Sebab di Madinah telah terbentuk asosiasi atau masyarakat yang dengan suka rela hidup diatur dengan sistem Islam beserta hukum-hukumnya. Sekalipun dalam komunitas masyarakat tersebut terdapat anggota masyarakat yang beragama selain Islam seperti Yahudi dan Nasrani. Konten dakwah yang diajarkan sekaligus dipraktekan Nabi pada periode ini seputar masalah kenegaraan dan kemasyarakatan. Kekuatan Islam pada periode Madinah semakin terbentuk kokoh dan kuat. Karena itu, dakwah tidak lagi mengandalkan bahasa lisan namun bahasa kekuasaan yang dijadikan sebagai metode untuk menerapkan dan mendakwahkan Islam. Lihat Ali Mustofa Ya'kub, Sejarah dan Metode Dakwah Nabi, Jakarta, Pustaka Firdaus, 2000). 76 
untuk masuk kedalam agama Islam sehingga untuk membangun kekuatan lebih dahulu. Dengan demikian, mereka memiliki peluang yang lebih besar untuk mengalahkan yang lain. ${ }^{6}$

Setelah Nabi Muhammad mendapat legitimasi kekuasaan dari penduduk Madinah melalalui proses bai'at, secara praktis Nabi memberlakukan hukum-hukum Islam atas penduduk Madinah yang heterogen. Hukum-hukum Islam yang berkaitan dengan pengaturan masyarakat dan negara pun banyak turun pada periode ini. Dengan demikian, posisi nabi bertambah menjadi kepala negara disamping sebagai kepala agama (pembawa risalah) yang memiliki wewenang untuk menerapkan prinsip-prinsip ajaran Islam. Dua kekdudukan berhasil beliau raih yaitu sebagai Rasul sekaligus kepala negara. ${ }^{7}$

Pergeseran peran Nabi Muhammad yang semula hanya penyampai risalah menjadi seorang pemimpin politik, memiliki pengaruh yang besar bagi perkembangan Islam di seluruh jazirah arab dan dunia. Menurut L. Stoddard, pada periode itu seakan nabi Muhammad SAW telah berhasil menjadikan padang pasir sebagai amunisi yang di sulut dari kota Madinah dan akhirnya meledak keseluruh jazirah Arab atau timur tengah. Sebab pasca hijrahnya Nabi Muhammad ke Madinah, dalam sejarah umat manusia beliau diakui sebagai tokoh paling sukses dalam mengubah dunia. ${ }^{8}$

Kesuksesan dakwah Nabi Muhammad di Madinah merupakan hasil nyata dari adanya harmoni agama dan politik. Keduanya membentuk satu kesatuan dalam mendobrak kejahiliahan umat manusia ketika itu. Dalam makalah ini akan dibahas tentang bagaimana kebijakan dan langkah-langkah dakwah Nabi Muhammad pada periode Madinah khususnya dalam membentuk masyarakat Islam dan menyebarluaskan Islam keseluruh penjuru dunia.

\section{Kerangka Teori dan Konseptual}

1. Definisi Dakwah

Dakwah merupakan kata yang berasal dari bahasa Arab yang terbentuk dari mashdar yaitu dari kata da'a, yad'u, da'watan. Artinya adalah ajakan, seruan atau panggilan. ${ }^{9}$ Segala bentuk seruan atau panggilan dapat dikatakan dakwah bila dilihat menurut kacamata bahasa.

Dalam salah satu karyanya, Al Bayanuni menjelaskan bahwa dakwah memiliki banyak varian makna. Dari banyak varian makna tersebut secara substansi memiliki tiga unsur utama yaitu penyampaian, pengajaran dan penerapan ajaran Islam dalam kenyataan hidup manusia sehari-hari. ${ }^{10}$ Sementara itu, subjek yang dibebani untuk menerapkan Islam terbagi menjadi

\footnotetext{
${ }^{6}$ Ahmad al-Usairy, Sejarah Islam (Sejak Zaman Nabi Adam Hingga Abad XX), Terj. Samson Rahman. (Jakarta, Akbar Media, 2013), 99-100

7 Muhamad Adnan, Wajah Islam Periode Mekah-Madinah dan Khulafaur Rasyidin, (Cendekia, Jurnal Studi Keislaman, Vol. 5 No. 1, Juni 2019), 93

8 Sujiat Zubaidi, Kritik. Epistimologi dan Model Pembacaan Kontemporer, (Yogyakarta, LESFI, 2013), 303

${ }^{9}$ A. Ilyas Ismail, Paradigma Dakwah Sayid Quthb, (Jakarta, Penamadani, 2006). 144

${ }^{10}$ Mohamad al Fatah al Bayanuni, al Makhad ila 'ilmi ad Dakwah, (Beirut, Muassasat al Risalah, 1991). 15
} 
empat yaitu; individu, keluarga, masyarakat dan negara. Maka dakwah secara seimbang harus mengenai keempat sasaran objek dakwah tersebut.

Dakwah memerlukan strategi atau metode yang digali dari fighud dakwah Nabi Muhammad. Dalam melaksanakan aktivitas dakwah, nabi Muhammad telah menempuh berbagi metode dan pendekatan tergantung objek dan situasi dakwah yang dihadapi. Secara umum, strategi dakwah yang dijalankan oleh Nabi melingkupi ceramah, dakwah interpersonal, tanya jawab, debat, masyirah dan sebagainya. ${ }^{11}$ Adakalanya Nabi Muhammad dakwah secara diam-diam dan dilain waktu dakwah secara terbuka.

Dalam rangka terlaksananya ideologi Islam secara menyeluruh dalam berbagai aspek kehidupan manusia, Islam mewajibkan seluruh pemeluknya untuk menjalankan kewajiban dakwah Islam. ${ }^{12}$ Melalui kewajiban dakwah inilah unsur-unsur fitrah manusia dapat terakomodir seperti kecintaan pada kebenaran, keadilan, keadilan dan keamanan.

Syarat mutlak bagi kesempurnaan dakwah yang akan membawa keselamatan hidup manusia adalah adanya amar ma'ruf nahi munkar yang ditujukan untuk melestarikan kema'rufan dan menghilangkan kemunkaran demi menciptakan kesempurnaan hidup bermasyarakat yang merupakan fitrah manusia sebagai makhluk sosial (makhluk ijtima'i). ${ }^{13}$ Dengan kata lain, dakwah memiliki orientasi bagi terbentuknya masyarakat Islam yaitu masyarakat yang menerapkan Islam sebagai sistem kehidupan.

Menurut Qurais Shihab, orientasi dakwah mestinya tidak berhenti pada aspek pemahaman keagamaan semata tetapi harus pada sasaran yang lebih luas yaitu aktualisasi ajaran Islam dalam seluruh lini kehidupan. ${ }^{14}$ Tanpa pelaksanaan ajaran Islam secara menyeluruh, karakter Islam yang rabmatan lil 'alamin akan sulit diwujudkan dalam kenyataan hidup manusia.

Selain itu, bagian penting dari dakwah yang merupakan syarat terwujudnya umat terbaik adalah pelaksanaan perintah amar ma'ruf nahi munkar (memerintahkan pada yang baik dan mencegah dari kemunkaran), sebagaimana firman Allah :

" kamu adalab umat yang terbaik yang dilabirkan untuk manusia, menyurub kepada yang ma'ruf, dan mencegah dari yang munkar, dan beriman kepada Allah. Sekiranya abli kitab beriman, tentulah itu lebih baik bagi mereka, di antara mereka ada yang beriman, dan kebanyakan mereka adalah orang-orang yang fasik. (QS Ali Imran : 110)

Memaknai ayat tersebut, Imam Ghazali menjelaskan bahwa ayat ini mengandung pengertian bahwa umat Islam merupakan sebaik-baik umat, dari awal hingga akhir, walaupun secara substansial ada perbedaan antar generasi, sebagaimana adanya dalil bahwa keunggulan sahabat melebihi atas yang lainnya. Namun demikian, prediket sebaik-baik umat akan melekat pada mereka selama

\footnotetext{
11 Asmuni Syukir, Dasar dasar Strategi Da'wah Islam, (Surabaya, al Ikhlas, 1983). 104

${ }^{12}$ Muhamad Abu Zahra, Ad Dakwah ila Islam, (Dar al Fiqri, tt). 129

${ }^{13}$ M. Natsir, Fiqhud Da'wah, (Jakarta, DDII, 1977). 26

${ }^{14}$ M.Quraish Shihab, Membumikan Al-Qur'an..., 194
} 
umat Islam konsisten menyeru kepada yang ma'ruf dan mencegah dari munkar. Bila ini tidak dilakukan maka prediket itu pun akan terlepas dari mereka. ${ }^{15}$

Lebih dari itu, ketika kewajiban dakwah ditinggalkan bukan saja hilangnya prediket sebagai umat terbaik dari umat Islam tetapi akan mendatangkan adzab Allah kepada umat manusia secara keseluruhan. Dalam hal ini, Ali bin Abi Thalib berkata 'Tidaklah musibah tersebut turun melainkan karena dosa. Oleh karena itu, tidaklah bisa musibah tersebut hilang melainkan dengan tobat." Maka musibah atau bencana merupakan bentuk teguran Allah kepada umat manusia agar mereka ingat dan kembali kepada syariat Allah SWT yang dibawa oleh nabi Muhammad. ${ }^{16}$

Selama berdakwah di Makkah, Rasulullah menekankan pada sisi kepercayaan yaitu dengan menanamkan keesaan Allah sebagai keyakinan yang kokoh dan bersih dari keraguan dan menanamkan keyakinan akan hari pembalasan setelah kematian yaitu kehidupan akhirat.

Adapun ketika Nabi hijrah ke Yastrib sebagai awal terbentuknya kekuasaan Islam, dalam dakwahnya Nabi Muhammad bukan semata menyeru secara lisan tetapi juga membuat kebijakan dan langkah praktis sesuai dengan posisinya sebagai kepala negara. Di antara kebijakan Rasulullah antara lain dengan mendirikan Masjid Nabawi sebagai pusat kegiatan masyarakat Islam, merajut persaudaraan antar anggota masyarakat yang heterogen, menciptakan struktur masyarakat dan pemerintahan yang kuat serta membuat perjanjian dengan kelompok non Muslim terutama kaum Yahudi yang bermukim di Madinah. Langkah Nabi Muhammad membuat perjanjian dengan non Muslim merupakan bukti bahwa negara Islam yang berpusat di Madinah bukanlah negara eksklusif yang tidak menghendaki perbedaan dan toleransi. Prinsip ini terus dipegang teguh oleh pemerintahan Islam sesudah nabi Muhammad terutama pada masa khulafaur rasyidin dan masa-masa kekhilafahan sesudahnya.

Selain itu, Nabi Muhammad pun menerapkan syariat Islam secara praktis dalam kehidupan masyarakat madinah yang baru sesuai dengan yang diwahyukan Allah terhadap beliau. Segala persoalan yang dihadapi masyarakat Madinah, muslim maupun non muslim, diserahkan kepada Rasulullah sebagai pemimpin negara Islam di Madinah. Dengan kata lain, Nabi memutuskan perkara hukum yang terjadi antar rakyat dengan rakyat atau antar rayat dengan pejabat menggunakan hukum Islam sesuai petunjuk wahyu.

Sifat keadilan hukum Islam yang diberlakukan tersebut pada akhirnya mampu menarik kepercayaan masyarakat Islam terhadap pengadilan Islam yang diberlakukan oleh Nabi Muhammad terahap mereka. Masyarakat senantiasa mempercayakan setiap perkara yang mereka hadapi untuk diadili oleh Nabi Muhammad SAW. Dengan tegaknya keadilan tersebut membuat masyarakat makin merasa aman dan nyaman.

\footnotetext{
${ }^{15}$ Imam Ghazali, Mukasyafatul Qulb, (Surabaya, Penerbit Amelia, tt). 88

${ }_{16}$ Ibnu Mas'ud,The Miracle of Amar Ma'ruf Nabi Munkar, Jogyakarta, Laksana,
} 2018). 138 
2. Konsep kekuasaan

Kekuasaan bukanlah istilah yang asing. Kata ini erat kaitannya dengan politik yang memiliki makna kemampuan manajerial dari seorang individu maupun kelompok dalam mengelola sumber kekuatan yang ada di tengah masyarakat sehingga dapat memperkokoh kekuasaan yang dimiliki yang dapat digunakan untuk mencapai tujuan tertentu.

Sumber kekuatan yang memiliki kemampuan memengaruhi dan mengendalikan masyarakat dapat berupa mahasiswa, media massa, elite politik dan militer. ${ }^{17}$ Melalui penguasaan terhadap sumber kekuatan ini, menurut Weber, maka individu atau kelompok memiliki potensi besar untuk mengendalikan dan memaksakan orang lain agar mengikuti berprilaku sesuai dengan kehendak atau kebijakan penguasa tersebut. ${ }^{18}$

Dalam pandangan Rosyadi, kekuasaan (power) masuk dalam substansi pokok pada pembahasan ilmu politik. Artinya pembahasan tentang kekuasaan muncul dalam kajian-kajian ilmu politik. Sementara kekuasaan sendiri kerap dimaknai sebagai kemampuan mengendalikan dan meyakinkan orang lain yang ada dalam kekuasaannya dengan kapasitas dan kapabilitas yang dimilikinya agar bergerak bersama meraih tujuan kepemimpinan atau kekuasaan. ${ }^{19}$

Atas dasar itu, Selo Sumarjan berpendapat bahwa dalam kehidupan masyarakat kekuasaan memiliki kedudukan yang sangat penting karena keberadaannya ikut menentukan nasib masyarakat yang hidup di bawah kekuasannya. ${ }^{20}$ Bila kekuasaan dipegang oleh orang baik dalam sebuah ideologi yang baik maka kekuasaan akan memunculkan kemaslahatan yang besar bagi berjuta-juta orang. Sebaliknya, bila kekuasaan dipegang oleh individu atau kelompok yang jahat maka masyarakat pun akan merasakan tekanan dan kedzaliman.

Sebagai makhluk sosial, kekuasaan sangat diperlukan dalam masyarakat sehingga keberadaannya selalu mengiringi kehidupan masyarakat dengan berbagai bentuknya, baik sederhana maupun kompleks. ${ }^{21}$ Tanpa ada kekuasaan maka akan membahayakan keberlangsungan hidup manusia yang membutuhkan ketenangan dan kedamaian walaupun tidak semua kekuasaan memunculkan dampak yang positif bagi kehidupan rakyat.

Secara sosiologis, kekuasaan dipandang sebagai unsur penting dalam menunjang kehidupan masyarakat namun tidak dalam perspektif baik dan

${ }^{17}$ Imam Hidayat, teori teori politik, (Malang, Setara Press, 2009). 31

${ }^{18}$ Rafael R.Maran, Pengantar Sosiologi Politik, (Jakarta, Rieneka Cipta, 2001). 190

19 Rosadi Kantaprawira, Sistem Politik Indonesia, Suatu Model Pengantar, (Bandung, Sinar Baru, 1983). 45

${ }^{20}$ Seorang Ulama Fudhail bin 'Iyadh berkata bahwa: "Seandainya aku memiliki doa yang mustajab, maka akan aku tujukan doa tersebut kepada pemimpin." Kemudian seseorang mengajukan pertanyaan kepada Fudail, 'mengapa demikian'?. Fudhail menjawab 'bila do'a itu aku tunjukan pada diriku semata maka bal tersebut sekadar bermanfaat bagi diriku. Akan tetapi bila doa itu aku tujukan pada penguasaku maka masyarakat dan negara akan menjadi lebih baik. 2002). 288

21 Surjono Soekanto, Sosiologi Suatu Pengantar, Jakarta, Raja Grafindo Persada, 
buruk. $^{22}$ Sebaliknya, dalam Islam, kekuasaan dipandang sebagai alat untuk menegakan nilai-nilai baik dan menghilangkan nilai-nilai buruk dalam masyarakat sesuai dengan prinsip ajaran Islam. Tujuan ini selaras dengan tujuan dakwah yaitu membentuk masyarakat Islam.

Kekuasaan dalam pandangan seorang pemikir politik barat bernama Machiaveli, sangat bergantung pada pengalaman empiris manusia. Karena itu, potensial sistem kekuasaan antar manusia disuatu tempat berbeda dengan yang lain. Lebih jauh, dia mengatakan bahwa kekuasaan memiliki otonomi yang terpisah dari ajaran moral, baik agama maupun moral yang berlaku dalam kehidupan masyarakat. Dia juga memiliki pendapat bahwa kekuasaan bukan merupakan alat untuk mewujudkan kebaikan-kebaikan dalam kehidupan masyarakat seperti keadilan dan kebenaran, akan tetapi, kekuasaan menurutnya merupakan alat untuk mengabdi pada kepentingan negara. ${ }^{23}$ Kepentingan negara tidak jarang dimaknai sebagai kepentingan para politisi yang mengendalikan negara tersebut. Pemikiran Machiaveli ini, walaupun banyak ditolak secara teoretis namun banyak diamalkan oleh para politikus di berbagai negara.

Berbeda dengan konsep kekuasaan yang difahami oleh Islam atau ulamaulama Islam, kekuasaan dalam Islam diilhami oleh ajaran Islam yang termaktub didalam beberapa ayat al-Qur'an, terutama yang tercantum dalam surat an Nisa ayat 58-59 yang artinya :

'sesunggubnya Allah menyurub kalian menunaikan amanat pada yang berhak menerimanya dan (menyuruh kamu) apabila menetapkan bukum di antara manusia supaya kamu menetapkan dengan adil. Sesunggubnya Allab memberikan pengajaran sebaik-baiknya kepadamu. Sesungguhnya Allab maha mendengar lagi maha melihat. (58)

Wahai orang-orangyang beriman, taatilah Allab dan taatilah Rasul (Nya), dan ulil amri di antara kamu. Kemudian jika kamu berlainan Pendapat tentang sesuatu, Maka kembalikanlah ia kepada Allah (Al Qur'an) dan Rasul (sunnabnya), jika kamu benarbenar beriman kepada Allah dan hari kemudian. yang demikian itu lebih utama (bagimu) dan lebih baik akibatnya. (59).

Para ulama mengkategorikan kedua ayat di atas sebagai dalil tentang urgensi kekuasaan terutama dari aspek tanggung jawab kekuasaan. Bahkan dalam ayat tersebut telah menghimpun prinsip-prinsip ajaran Islam yang agung tentang kekuasaan serta penegasan tentang kekuasaan Allah swt sebagai parameter manusia dalam menjalankan kekuasaan di muka bumi.24

Sekalipun dunia Islam saat ini banyak dipengaruhi pemikiran sekular ala barat yang cenderung memisahkan agama dari kekuasaan namun dalam pandangan Al Ghazali kekuasaan dan diin memiliki hubungan yang tidak dapat dipisahkan. Bahkan keduanya seperti dua saudara yang dilahirkan kembar

\footnotetext{
${ }^{22}$ Ibid, 230

${ }^{23}$ Rapar, JH, Filsafat Politik. Plato, Aristoteles, Agustinus, Machiavelli, (Jakarta, Raja Grafindo Persada, 2001). 430

24 Abd Mu’in Salim, Fikih Siyasah, (Jakarta, PT Raja Grafindo, 2002). 175
} 
dalam perut yang sama. ${ }^{25}$ Maka memisahkan hubungan keduanya bertentangan dengan prinsip ajaran Islam baik dilihat dari aspek teologis maupun historis.

Atas dasar itu, pembentukan negara sebagai wadah kekuasaan yang legal adalah wajib secara syar'i. Kewajiban ini didasarkan pada ijmak sahabat yang masuk dalam kategori fardu kifayah. Secara historis, ijmak ini terlihat dari peristiwa pembai'atan sahabat Abu Bakar sebagai khalifah pasca wafatnya Rasulullah SAW. Dalam figh siyasah peristiwa ini banyak dijadikan sebagai dalil tentang urgensi kekuasaan dalam Islam yang diterima oleh umat secara kolektif paling tidak sejak masa pemerintahan Abu Bakar hingga masa imam Ghazali dan beberapa abad setelahnya.

\section{Dakwah Nabi Muhammad pada periode Madinah}

Masifnya gerakan dakwah Nabi Muhammad di Mekah, menyebabkan Rasul dikenal oleh masyarakat seantero jazirah Arab hingga di kota Yastrib. Kota ini kemudian dikenal dengan nama Madinah. Para penduduk Yastrib, baik dikota maupun desa, melihat dan mendengar kabar tentang dakwah Rasulullah melalui interaksi bisnis dan perdagangan.

Periode dakwah Madinah dimulai ketika beberapa orang penduduk Madinah menerima dakwah Nabi Muhammad dan mengikrarkan diri mereka sebagai muslim. Peristiwa ini terjadi pada tahun ke-11 sejak Nabi Muhammad diangkat menjadi Rasul. ${ }^{26}$ Akhirnya, berselang satu tahun pasca peristiwa ini, para tokoh di Madinah mengutus sebanyak dua belas orang untuk menjumpai Rasulullah di kota Mekah. Momen pertemuan tersebut berlanjut pada perpindahan kekuasaan kepada Nabi Muhammad melalui prosesi bai'at I dan II.

Menurut Ahmad Sukarja, substansi dari bai'at pertama lebih menekankan pada aspek moral dan tidak memiliki konsekuensi perlindungan dari ancaman apabila keselamatan Rasulullah terancam. ${ }^{27}$ Karena bai'at ini melibatkan seorang wanita bernama Afra bin Abid maka bai'at ini dikenal juga dengan bai'at an nisa'.

Bai'at aqabah pertama ini kemudian diikuti dengan bai'at aqabah dua yang isinya : "Kami akan melindungimu sebagaimana kami melindungi wanita kami. Kami adalah tukang perang dan selalu bertengkar. Jika kami memutuskan hubungan dengan kaum Yahudi, sudikah anda membela kaumku?" Jawab Nabi: "Darahmu darahku, perlindungamu perlindunganku, kalian bagian jiwaku, aku akan memerangi

\footnotetext{
25 Abu Hamid Al Ghazali, Etika Berkuasa, Nasehat-nasehat Imam Ghazali, (Bandung, Pustaka Hidayah). 90

26 Peristiwa ini dimulai ketika sekelompok orang khazraj datang ke kota Mekah menemui Rasul pada musim haji. Pada pertemuan tersebut, Rasul mengajak mereka berdialog dan menanyakan kabar serta mengajak untuk masuk Islam. Mendengar tawaran tersebut, mereka saling menunggu sikap dari kawannya dengan saling berpandangan. Salah seorang diantara mereka mengatakan 'wallahi, sebenarnya dia merupakan salah seorang Nabi yang pernah dijanjikan kedatangannya oleh orang Yahudi kepada kalian.' Akhirnya, keseluruhan dari suku khazraj ini seluruhnya masuk Islam sembari berharap akan persatuan suku auz dan khazraj melalui agama yang baru mereka anut tersebut (Islam). Lihat Syaikh Taqiyudin an Nabhani, Daulah Islam, (Bogor, Pustaka Thoriqul Izzah, 2002). 47

27 Achmad Sukarja, Piagam Madinah dan UUD 1945, (Jakarta, UI Press, 1995). 84
} 
musuh kalian dan aku akan berdamai dengan siapa saja yang berdamai dengan kalian"28

Peristiwa bai'at aqabah I dan II selanjutnya menjadi modal awal bagi Nabi Muhammad untuk menancapkan pilar-pilar bangunan masyarakat Islam di Madinah. Setidaknya ada beberapa karakteristik yang dapat dilihat pada aktivitas dakwah beliau di Madinah yaitu : pertama, melakukan pembinaan bagi penduduk Madinah yang menerima Islam melalui kelompok-kelompok kecil dalam perhalaqahan. Kedua, membentuk sistem ketatanegaraan baru dalam bentuk negara Islam. Ketiga, menerapkan hukum Islam atas seluruh lapisan masyarakat yang hidup dalam naungan daulah Islam secara serius. Keempat, membangun kerja sama dengan non muslim yang ingin hidup dalam naungan sistem Islam secara damai dan tetap bermuamalah dengan standar aturan yang telah ditetapkan dalam Islam. ${ }^{29}$

Dakwah Nabi Muhammad pada periode Madinah merupakan tonggak kemenangan Islam. Sebab, dengan kekuasaan itu dakwah Nabi Muhammad memiliki kekuatan yang diikuti oleh umat dan disegani oleh lawan sehingga Islam dengan mudah menyebar dan diterima oleh masyarakat dunia. Menurut Harun Nasution, atas kebijakan Umar bin Khatab peristiwa hijrahnya Nabi Muhammad ke Madinah pada tahun $622 \mathrm{M}$ dijadikan sebagai tonggak atau awal tahun baru Islam (tahun Hijriah). Sebab dengan kekuasaan baru Nabi Muhammad di Madinah itu, Islam pun mendapat kan banyak kemudahan untuk diterima masyarakat. Dengan demikian, Islam mulai merambah pengaruhnya secara politik ke berbagai wilayah disekitar jazirah Arab. Pada perkembangan selanjutnya, kekuasaan Islam mampu menyebarkan sayap dakwah hingga ke Spanyol, Filipina dan Afrika. ${ }^{30}$

Dalam teori modern, hubungan dakwah dan kekuasaan yang dipraktekan Nabi Muhammad pada periode madinah adalah teori integralistik dan simbiotik. Dalam paradigma teori ini, Islam diyakini tidak sebatas aturan yang hanya melibatkan manusia dengan Tuhan melainkan mengatur juga hubungan antar manusia dalam berbagai aspeknya seperti aspek keluarga, hukum, politik, sosial, budaya dan ekonomi. Melalui paradigma ini, kesempurnaan ajaran Islam difahami sebagai innnal Islam Din wa Daulah, sehingga relasi keduanya terbentuk secara formalistik-legalistik dalam pola sebuah sistem Islam. ${ }^{31}$

Secara fungsional, menurut al-Mawardi, negara memiliki kedudukan sangat vital dalam dalam kehidupan masyarakat Islam terutama dalam pemeliharaan agama. Melalui fungsi dan kekuatan negara, hukum-hukum Islam dapat direalisasikan secara nyata seperti berbagai persoalan hukum, politik, militer, pidana serta perdata yang secara jelas diatur dalam Islam. ${ }^{32}$

\footnotetext{
${ }^{28}$ Ibid, 86

${ }^{29}$ Mohammad Arif, Dinamika Islamisasi Makkah \& Madinah, (Asketik Vol. 2 No. 1, Juli 2018). 56

${ }^{30}$ Prof. Harun Nasution, Islam ditinjau dari Berbagai Aspeknya, (Jakarta, UI Press, 1979). 34

31 Abd Aziz Taba, Islam dan Negara dalam Politik Orde Baru, Jakarta, Gema Insani, 1996). 42

32 Abd Qodim Zalum, Pemikiran Politik Islam, (Bangil, Izzah, 2001). 155
} 
Merujuk pada praktik relasi agama dan negara dalam kehidupan umat Islam masa Rasulullah, negara memerlukan fondasi agar dapat menopang keberlangsungan sistem Islam, yaitu : Pertama, negara harus menjadikan Islam sebagai rujukan utama dalam menjalankan roda pemerintahan melalui penggalian hukum-hukum Islam oleh imam mujtahid. Kedua, negara harus dipimpin oleh sosok yang memiliki kapasitas, integritas dan otoritas yang secara langsung melekat dalam diri seorang pemimpin. Dengan integritas yang dimiliki seorang pemimpin dapat menyikapi berbagai perbedaan dalam masyarakat secara bijak dan tepat sehingga tercipta tatanan masyarakat Islam yang kuat, damai, adil dan makmur. Ketiga, terciptanya rasa keadilan dalam kehidupan masyarakat sebagai implementasi dari penerapan ajaran Islam secara benar di tengah masyarakat. keempat, terciptanya keamanan yang akan mendorong situasi yang kondusif ditengah-tengah masyarakat sehingga menciptakan daya kreativitas dalam pembangunan masyarakat dan negara. Kelima, memelihara dan merawat kualitas lahan-lahan pertanian secara konsisten dan terus-menerus sehingga menguatkan ekonomi rakyat terutama dalam bidang pangan. Keenam, memelihara harapan dan kemampuan untuk berkembang dalam berbagai bidang kehidupan. ${ }^{33}$

Sementara menurut teori simbiotik, agama dan negara tercipta relasi yang simbiotik atau saling memerlukan terutama dalam mewujudkan kemaslahatan bagi masyarakat. ${ }^{34}$ Sikap dan kebijakan Nabi Muhammad dengan menjadikan kekuasaan sebagai metode untuk menerapkan Islam, menyebarkan dan melindungi dakwah Islam menunjukkan bahwa telah terjadi integrasi dan simbiosisasi antara agama dan politik.

Beberapa aktivitas dan langkah yang dilakukan Nabi Muhammad SAW dalam memuluskan dakwah di Madinah dengan posisinya sebagai kepala negara, yaitu : ${ }^{35}$

\section{Membangun masyarakat}

Struktur dan kondisi masyarakat Arab sebelum Islam dikenal dengan masa jahiliah. Ketika Islam datang, sedikit demi sedikit budaya Arab yang buruk mulai terkikis sehingga terbentuklah masyarakat Islam ketika dakwah Nabi Muhammad hijrah ke Madinah. Pertama yang dilakukan dalam upaya membangun masyarakat Islami di Madinah adalah dengan cara membangun

33 Suyuti Pulungan, Fikih Siyasah, Ajaran, Sejarah dan Pemikiran, Jakarta, Raja Grafindo Persada, Cet. 4, 1999). 227

${ }^{34}$ Ahmad Safi'i Maarif, Islam dan Politik di Indonesia pada Masa Demokrasi Terpimpin (1959-1965), (Yogyakarta, IAIN Sunan Kalijaga Press, 1988). 195.

35 Pembahasan tentang fakta posisi nabi Muhamad sebagai pemimpin negara di Madinah mestinya dapat dijadikan sebagai tauladan oleh para penyelenggara negara dimana pun dan kapan pun terutama untuk membentuk masyarakat yang maju dan berperadaban. Sebab bangunan masyarakat yang dipola oleh Nabi Muhamad telah berhasil membalikan kondisi masyarakat arab jahiliah menuju cahaya Islam yang kemudian menjadi mercusuar peradaban. 
masjid ${ }^{36}$ sebagai infrastruktur fisik utama yang sederhana namun multifungsi, yakni masjid Nabawi. ${ }^{37}$

Pada waktu itu, di kota Madinah ada tiga kelompok masyarakat. Pertama, kaum muslimin dari golongan Muhajirin yaitu umat Islam yang hijrah ke Madinah dan golongan Anshor yaitu umat Islam yang menyambut dan menolong saudara mereka dari golongan muhajirin. Kedua, suku Aus dan Khazraj, mereka adalah kaum musyrik di Madinah yang terlibat konflik berkepanjangan. Ketiga, kelompok Yahudi. ${ }^{38}$

Dalam membangun masyarakat baru di Madinah, setidaknya nabi menyiapkan strategi yang berisikan dua fragmen yaitu formal dan mental spiritual. ${ }^{39}$ Kedua unsur ini secara efektif mampu menyatukan masyarakat Islam yang baru sehingga membentuk kekuatan tersendiri bagi umat Islam yang berpengaruh besar bagi perkembangan Islam pada masa itu dan sesudahnya.

Adapun langkah formal yang Rasulullah terapkan atas masyarakat Islam di Madinah adalah :

1. Memberlakukan peraturan dalam bentuk undang-undang yang mengikat bagi seluruh rakyat yang meliputi seluruh bidang kehidupan

2. Kepemimpinan yang ditaati oleh seluruh rakyat terutama kaum muslimin berikut jaminan keamanan yang diberikan kepada Rasulullah sebagai pemimpin.

3. Dibentuknya sistem ketentaraan yang mampu melindungi pemerintahan dan undang-undang yang diberlakukan atas masyarakat

4. Memiliki sumber ekonomi yang kuat bagi negara sehingga negara mampu membiayai penyelenggaran negara

5. Masyarakat Islam telah memiliki orientasi hidup yang sama yaitu untuk mengabdi kepada Allah SWT dengan segala konsekuensinya.

6. Memiliki batas-batas tanah air yang tetap. ${ }^{40}$

${ }^{36}$ Pada masa awal dakwah periode Madinah, Rasulullah menjadikan Masjid Nabawi sebagai pusat kegiatan umat, dakwah dan pemerintahan. Pria dan Wanita dari segala usia diberikan kesempatan untuk mempelajari Islam di Masjid tersebut. Orang dewasa menggunakan Masjid sebagai tempat untuk mempelajari Islam yang meliputi Al-Qur'an, hadits,fiqih dan bahasa Arab. Bagi wanita, selain mempelajari ilmu-ilmu Islam juga belajar keterampilan seperti menenun atau memintal. Di pelataran Masjid anak-anak belajar materi al-Qur'an, bahasa Arab, berhitung, berkuda, berenang dan memanah. Lihat Abdulah Idi dan Soekarto, Revitalisasi Pendidikan Islam, (Jogyakarta, Tiara Wacana, 2006). 81 2009). 28

${ }^{37}$ Ibrahim dan Darsono, Tonggak Sejarah Kebudayaan Islam, (Solo, Tiga Serangkai,

38 Taqiyudin an Nabhani, Daulah Islam, 71

39 Zaenal Abidin, Konsep Politik dan Ideologi Islam, (Jakarta, Bulan Bintang, 1977). 163

${ }^{40}$ Jamaludin Kafi, Islam Agama dan Negara, (Surabaya, Bina Ilmu, 1983), 48. Dalam sejarah Islam, wilayah kekuasaan Islam bersifat berubah-ubah sesuai dengan kekuatan dan misi dakwah yang menjadi kebijakan negara. Pada mulanya Islam hanya berkuasa di Madinah lalu bergerak menguasai Mekah dan Jazirah arab. Namun, wilayah Islam meluas pada masa kekhalifahan Usman bin Affan pada masa pemerintahannya yaitu antara tahun 644 hingga 656 M. Beberapa wilayah yang berhasil ditaklukan dan menjadi bagian dari kekhilafahan 
Semua unsur-unsur formal tersebut merupakan syarat terbentuknya negara. Tanpa adanya salah satu dari unsur tersebut maka kestabilan negara akan sulit dijaga. Namun demikian, unsur formil tidaklah cukup maka diperlukan unsur kedua untuk membangun masyarakat yaitu unsur mental spiritual.

Unsur mental dalam konteks pembangunan masyarakat di Madinah terdiri atas : pertama, terbangunnya rasa persaudaraan antar kaum Muhajirin dan Anshar sebagai hasil dari kebijakan nabi Muhammad pada awal kepemimpinan beliau di Madinah. Kedua, menghapuskan permusuhan antar suku yang disebabkan sentimen kesukuan dan kelompok. Ketiga, membangun persaudaraan di atas ajaran dan spirit Islam dan menegasikan aspek kesukuan dan kedaerahan. Keempat, menghapuskan benih-benih dendam jahiliah pada masyarakat Islam di Madinah. ${ }^{41}$

\section{Pendekatan hukum}

Pada periode Madinah, selain membangun masyarakat juga seperti dikemukakan pada pembahasan terdahulu juga melalui pendekatan hukum. Pada saat itu, pelaksanaan konstitusi menjadi otoritas Nabi Muhammad SAW secara penuh sebab kebijakan Nabi sebagian besar merupakan bagian dari wahyu yang wajib diterapkan dan dilaksanakan oleh masyarakat Islam di Madinah tanpa campur tangan pihak lain. Melalui kewenangan hukum itu, Nabi Muhammad menghukumi masyarakat Islam dengan hukum yang bersumberkan pada al-Qur'an ataupun Sunah.

Kepercayaan masyarakat Islam yang tinggi terhadap Islam berikut hukum-hukum yang diturunkan kepada mereka melalui Rasulullah, maka terciptalah masyarakat yang damai dan hampir belum pernah terjadi perselisihan di dalam hukum. Permasalahan dan pertanyaan masyarakat Islam pada periode itu langsung dijawab dengan turunnya ayat-ayat al-Qur'an sebagai hukum yang memutuskan perkara mereka. Sehingga pada periode ini umat Islam telah terbina menjadi satu pemerintahan dan dakwah berjalan dengan baik tanpa tantangan yang berarti. ${ }^{42}$

Implementasi dakwah oleh negara dapat dilaksanakan dengan menggabungkan aspek fisik dan pemikiran sekaligus. Hal ini dikarenakan negara dapat secara langsung menerapkan inti dakwah yaitu ajaran Islam dalam bentuk kebijakan-kebijakan di tengah masyarakat. Pelaksanaan Islam secara praktis tersebut akan memiliki dampak yang signifikan bagi terbentuknya masyarakat Islam yang kokoh sesuai dengan tujuan dakwah. Keindahan Islam hadir bukan semata terdengar melalui klaim-klaim para da'i dalam ceramah dan khotbahkhotbahnya tetapi dapat secara nyata disaksikan dan dirasakan. Sistem hukum dan pemikiran Islam secara aktif mampu menciptakan lompatan-lompatan

Islam meliputi Tunisia, Cyprus, Armenia dan sebagian wilayah Persia, Transoxania dan Tabaristan. Lihat Badri Yatim, Sejarah Peradaban Islam, (Jakarta, PT Raja Grafindo, 2015). 38

${ }^{41}$ Zainal Abidin Ahmad, Op.Cit, 165

${ }^{42}$ Roibin, Dimensi Historitas dan Normatifitas Penetapan Hukum Islam Pada Masa Rosulullah, dalam http:/ / syariah.uin.malang.ac.id, diakses 16 April 2020 
peradaban yang menarik perhatian seluruh umat manusia. Sehingga, menurut pengakuan barat, tanpa sumbangsih peradaban Islam masa pencerahan di Eropa tidak akan terjadi. ${ }^{43}$ Suatu fakta historis yang menunjukan bahwa peradaban yang dibangun diatas fondasi Islam akan mampu menciptakan tatanan masyarakat yang maju, adil dan makmur.

Kondisi masyarakat yang dibangun di atas aqidah dan hukum Islam akan melahirkan gairah dakwah bagi masyarakat tersebut sehingga mendorong mereka untuk menyebarkan Islam sebagai ideologi pada dunia. Sebagai agama dakwah, Islam secara aktif terus disosialisakan baik oleh negara, jamaah/kelompok masyarakat maupun individu. ${ }^{44}$ Tentu dengan tetap memperhatikan substansi pemikiran Islam yang dikembangkan di tengah masyarakat agar ada jaminan bahwa masyarakat mendapatkan faham keagamaan yang benar.

Pada periode Madinah, komunitas yang membentuk masyarakat Islam baru terwujud. Karena itu, Nabi membuat fondasi atau dasar-dasar kekuasaan yang kuat disemua aspek dari mulai bidang sosial, ekonomi maupun politik dan hukum. Terbentuknya fondasi yang kokoh sangat penting untuk dijadikan sebagai pijakan bagi pemerintahan sesudah Rasulullah sehingga dalam kurun waktu sepuluh tahun kepemimpinan beliau di Madinah berhasil menghasilkan pengaruh yang besar bagi perkembangan Islam. ${ }^{45}$ Bahkan pasca wafatnya Nabi, fondasi itu tetap kokoh dan tetap menjadi pijakan pemerintahan Islam pada masa-masa sesudahnya yaitu dari masa khulafaur rasyidin hingga masa kekhilafan Utsmani dengan berbagai dinamika yang terjadi.

Di sisi lain, makin luasnya pengaruh Islam dalam kehidupan masyarakat tentu saja memerlukan wadah dan sistem untuk mengatur berbagai dinamika dalam masyarakat Islam. Untuk itu, melalui wahyu, Nabi Muhammad kemudian meggunakan pendekatan hukum Islam untuk mengatur kehidupan masyarakat baik antar individu maupun antar negara. Salah satu pendekatan hukum yang dilakukan oleh Nabi Muhammad dalam membina masyarakat Islam yang baru di Madinah adalah dengan menerapkan pidana Islam atau yang dikenal dengan istilah budhud. ${ }^{46}$ Seperti perzinahan, pencurian dan pembunuhan. Sangsi hudhud dalam sejarah Islam baru turun pada periode Madinah masa dimana kekuasaan Islam berhasil diraih oleh Nabi Muhammad sehingga memungkinkan untuk mengadili manusia di wilayah kepemimpinan Islam dengan hukum Islam seperti qishas pada kasus pembunuhan atau tindakan kriminal, memotong tangan

43 Abdurahman Mas'ud, Paradigma Islam Rahmatan Lil 'Alamin, (Yogyakarta, IRCiSoD, 2021). 63

${ }^{44}$ Hamka Haq, Syariat Islam, Wacana dan Penerapannya, (Ujung Pandang, Yayasan al Ahkam, 2001). 103

${ }^{45}$ Nashrah, Nabi Muhamad Sebagai Pemimpin Agama dan Negara, (e-USU, 2005). 10

${ }^{46}$ Menurut Ali bin Muhamad al-jurjani, makna hudhud adalah sanksi hukum yang jumlah maupun bentuknya sudah ditetapkan oleh Allah kepada orang yang melanggarnya. Hudhud merupakan hak Allah sehingga pemberlakuannya wajib dilakukan oleh negara dan tidak boleh diganti dengan hukum positif buatan manusia. Lihat Abubakar Jabir al-Jurjzani, Minhaj al Muslim Kitab wa Akblak wa Ibadah wa Muamalab, Cet. VIII, (Al-Madinatul alMunawarah , 1976). 453 
pencuri apabila telah memenuhi syarat-syarat pemberlakuannya, merajam pelaku zina muhson serta memberikan hukuman cambuk bagi peminum khamr. ${ }^{47}$

Seluruh penerapan sangsi dalam Islam selain merupakan implementasi ketataan masyarakat Islam terhadap Allah, dalam setiap hukum tersebut memiliki hikmah-hikmah yang sebagian dapat dirasionalkan. Seperti sangsi terhadap pezina. Dalam Islam, zina merupakan perbuatan kriminal yang mendapatkan hukuman cukup berat yaitu rajam hingga mati. Penerapan hukum rajam terhadap pezina ini sangat penting dalam menjaga kesucian masyarakat di Madinah ketika itu. Merajalelanya zina akan berdampak pada ruwetnya tatanan sosial yang lain seperti aturan Islam tentang hukum pewarisan, pernikahan dan dapat merembet pada persoalan keamanan dan ketertiban.

Demikian pula pidana pencurian. Pada masa Nabi Muhammad, hukum pencuri adalah potong tangan. Hukuman ini telah ditetapkan dalam al-Qur'an dan sunah Nabi. Diriwayatkan dari Sayidah Aisah, istri Rasulullah SAW. Bahwa Aisyah pernah bertanya pada Nabi, 'adakah sebuah dispensasi yang bisa diberikan berkaitan dengan bukum potong tangan bagi pencuri. Mendengar pertanyaan tersebu Nabi lantas berdiri dan bersabda: suatu kerusakan akan terjadi pada suatu kaum ketika meninggalkan bukuman pada seseorang yang berpunya (kaya) namun melaksanakan bukum pada orang yang miskin dan lemah. ${ }^{48}$

Ketegasan Nabi dalam menegakan budhud bagi pencurian ini terlihat dari penolakan beliau memberikan dispensasi atau keringanan sangsi atas kasus pencurian yang melibatkan keluarga al-Mukhzumiah. Permohonan dispensasi ini diajukan oleh Usamah, orang dekat Rasulullah. Menanggapi permintaan itu, setelah pencurian itu terbukti, Rasulullah bersabda "demi Allab sekalipun anak saya Fatimah Az-zahra bila terbukti mencuri maka akan potong tangannny". ${ }^{49}$ Sikap Rasulullah ini memiliki dua hikmah. Pertama, penegakan hukum harus dilaksanakan secara adil, tidak pandang bulu. Siapa pun yang terlibat dalam perkara hukum, baik pejabat maupun rakyat, maka harus dihukum sesuai dengan perkara yang dihadapi sesuai ketentuan Islam. Kedua, keteladanan Nabi Muhammad terhadap proses penegakan hukum sangat penting untuk umatnya karena ada keteladanan Nabi sebagai uswatun hasanah.

\section{Mendakwahkan Islam}

Pada periode Madinah, sebagai kepala negara Nabi Muhammad tidak berhenti berdakwah. Dengan kekuasaan dan pengaruhnya yang makin besar, beliau melakukan upaya-upaya dakwah dengan memanfaatkan kewenangan atau kekuasaan yang beliau miliki untuk mengembangkan misi dakwah. Dakwah tidak lagi terbatas pada ajakan lisan melalui ceramah maupun ajakan yang dilakukan secara personal. Berbeda dengan pendekatan dakwah di mekah, pada periode Madinah dilaksanakan dengan metode sebagai berikut :

\footnotetext{
47 Ahmad Sarwat, Madinab era kenabian, (Jakarta,Rumah Fiqh Publishing, 2018). 14

${ }^{48}$ Ibn Hajar al-Asqalani, Bulughul Maram, (Darul Bayan, Cet 1, 2006). 261

${ }^{49}$ Muhamad Said Ishaq, Islam Membebaskan Manusia, (Malaysia, Daul Ta'zim, cet. 2,
} 2002). 65 
Pertama, pengiriman ekspedisi militer. Dalam upaya mengenalkan Islam kepada dunia, Nabi Muhammad makin tegas dan berani dalam berdakwah pada periode Madinah yaitu dengan mengirim utusan kepada para pembesar sukusuku di luar jazirah Arab.

Pengiriman ekspedisi militer ini dilakukan oleh Nabi, terutama setelah peristiwa perang khaibar berlalu. Pertama-tama beliau mengirim beberapa ekspedisi militer kepada suku-suku badui di semenanjung Arab dengan ketentuan bila mereka menerima Islam mereka akan selamat tetapi bila sukusuku itu melakukan perlawanan maka utusan muslim diperkenankan melakukan penyerangan. ${ }^{50}$

Kedua, memperhatikan masyarakat kecil yang baru masuk Islam. Pada awal terbentuknya kekuasaan Islam di Madinah, tidak sedikit kaum dhuafa yang masuk Islam. Mereka datang dari luar Madinah sehingga bukan merupakan dari golongan muhajirin maupun anshor.

Kemiskinan yang mereka derita mendorong Nabi untuk menyelamatkan aqidah mereka yaitu dengan menampung mereka di sebuah tempat khusus yang berada di serambi Masjid yang digunakan sebagai tempat perlindungan. Nafkah mereka ditanggung oleh umat Islam, baik dari golongan muhajirin maupun anshor yang memiliki kelebihan harta. ${ }^{51}$ Tindakan Nabi SAW ini penting untuk menjadi pelajaran bagi umat Islam khususnya para pengemban dakwah bahwa dakwah bukan semata memberikan asupan pemikiran dan pemahaman Islam tetapi harus diiringi dengan kepedulian terhadap masalah ekonomi masyarakat sebagai mad'u. Sekalipun demikian, hal ini tidaklah mutlak karena kesejahteraan sejatinya merupakan tanggung jawab negara.

Ketiga, mengangkat gubernur. Sebagai kepala negara, Nabi memiliki wewenang untuk mengangkat gubernur guna menjaga eksistensi dakwah dan pelayanan kepada masyarakat. Salah satunya dengan menugaskan para gubernur dan petugas zakat ke berbagai wilayah kekuasaan Islam untuk menarik zakat dan membagikannya kepada orang yang berhak. ${ }^{52}$ Langkah ini, selain merupakan implementasi dari syariat dan kewajiban zakat juga merupakan bukti bahwa dakwah yang dilakukan oleh negara memiliki peran untuk menciptakan kesejahteraan bagi masyarakat.

Keempat, pengiriman surat kepada raja-raja untuk memeluk Islam. Sebagai kepala negara, secara politik Nabi memiliki kedudukan yang sejajar dengan kepala negara lain. Untuk itu, Nabi berkirim surat kepada raja-raja pada masa itu melalui para utusan yang bertugas mengantarkan surat tersebut diantaranya Nabi mengutus Abdullah bin Hudzafah kepada Kisra Persia, Dihyah bin Khalifah al-Kalbi kepada kaisar Byzantium Romawi, Amr bin Umayah kepada raja Najasyi, Hathub bin Abu Balta'ah kepada al Muqaiqis di Iskandariyah, al Muhajir bin Abu Umayah kepada raja Yaman, al-Harits bin

\footnotetext{
50 Said Ramadhan al Buthi, Fiqh Sirah ma'a Mu'jaz litarikh ar rosyidah, (Dar al Fikr, Damaskus, 2009). 445

51 Taqiyudin an Nabhani, Daulah Islam, 72-73

52 Ibnu Ishak, Syarah dan tahqiq Ibnu Hisyam Sirab Nabawi, (Jakarta, Akbar Media). 
Abdu Khalal dan sebagainya. ${ }^{53}$ Seluruh surat dakwah yang disampaikan Nabi mendapatkan tanggapan yang beragam dari para raja dan penguasa yang semuanya menunjukkan bahwa kepala negara dalam Islam memiliki kewajiban untuk mengajak manusia kepada Islam sebagai implementasi keyakinannya bahwa Islam adalah agama yang paling benar dan agama satu-satunya yang dapat menyelamatkan manusia dari kesengsaraan hidup di dunia dan akhirat.

Dari keempat aktifitas dakwah Rasulullah di atas, dakwah Rasulullah menuai sukses besar sehingga dengan kesuksesan itu mampu mengubah wajah peradaban Arab jahiliah kepada wajar peradaban Islam yang diliputi kegemilangan. Hukum dan sistem jahiliah berhasil dirubah sama sekali menjadi hukum dan sistem Islam yang kemudian berhasil mengangkat derajat bangsa Arab dan umat Islam secara umum kepada abad kegemilangan. Dengan kekuatan dan keagungannya, Islam berhasil menjadi agama yang banyak diterima oleh umat manusia di dunia.

\section{Penutup}

Berdasarkan kajian terhadap dakwah Nabi Muhammad di Madinah, dapat disimpulkan bahwa :

Pertama, secara sosiologis historis, kesuksesan dakwah Nabi Muhammad di Madinah bermula dari adanya dukungan secara politik dari tokoh-tokoh di Madinah. Mereka memberikan bai'at berupa komitmen untuk beriman kepada Allah, meninggalkan keharaman dan pada akhirnya memberikan jaminan keamanan dan dukungan terhadap Nabi Muhammad SAW. Peristiwa ini mendorong Nabi Muhammad, atas petunjuk wahyu, untuk hijrah dan membangun kekuatan di Madinah dengan melakukan pembinaan, pelayanan dan penerapan Islam secara menyeluruh terhadap setiap ayat yang turun.

Kedua, beberapa langkah strategis yang dilakukan Nabi Muhammad SAW ketika meletakkan fondasi sekaligus membangun masyaakat di Madinah yaitu : (1) membangun Masjid sebagi pusat kegiatan keumatan baik bidang ekonomi, hukum, politik bahkan jihad atau militer. (2) mempersaudarakan kaum muhajirin dan ansor dalam satu ikatan yaitu ikatan Islam. (3) membuat perjanjian damai dengan orangorang non muslim yang tidak memerangi Islam. (4) menerapkan hukum Islam sebagai konstitusi untuk mengatur masyarakat Islam yang baru. (5) meluaskan dakwah dan jihad ke berbagai wilayah diluar jazirah Arab.

Keempat, dalam masyarakat Islam, perbedaan agama tidak menjadi sandungan untuk merajut persatuan dan persaudaraan. Di bawah sistem pemerintahan Islam, masyarakat dapat hidup damai dan rukun sekalipun berbeda agama dan keyakinan. Sebab Islam menganut prinsip 'bagiku agama-ku dan bagi-mu agama-mu'.

Kelima, keberhasilan Nabi Muhammad dalam mengelola pemerintahan berdasarkan Islam seyogianya dapat dijadikan teladan oleh pemimpin muslim terutama dalam menghadirkan Islam yang rahmatan lil 'alamin. 
Keenam, penelitian ini menekankan pada aspek historis terkait relasi dakwah dan kekuasaan khususnya yang dipraktikan oleh Nabi Muhammad SAW. Dengan demikian, agar penelitian ini makin dirasakan manfaatnya bagi kehidupan sosial dan bernegara saat ini maka perlu adanya riset-riset lanjutan tentang implementasi kekuasaan (power) bagi perkembangan dakwah baik dalam ranah negara, organisasi Islam maupun institusi-institusi lainnya.

\section{Daftar Pustaka}

Adnan, Muhammad, Wajah Islam Periode Mekah-Madinah dan Khulafaur rasyidin, Cendekia, Jurnal Studi Keislaman, Vol. 5, No. 1, Juni 2019

Agama, Departemen, Al Quran dan Tarjamahnya, Bandung, CV Diponegoro, 2006

Ahmad, Zaenal Abidin, Konsep Politik dan Ideologi Islam, Jakarta, Bulan Bintang, 1977

Al Asqalani, Ibn Hajar, Bulughul Maram, Darul Bayan, Cet 1, 2006. HR Al Bukhari, hadits No. 2695 dan 269

Al Buthi, Said Ramadhan, Dr. Figh Sirah ma'a Mu'jaz litarikh ar rosyidah, Dar al Fikr, Damaskus, 2009

Al Ghazali, Abu Hamid, Etika Berkuasa, Nasihat-Nasihat Imam Ghazali, Bandung, Pustaka Hidayah, 1988

Al-Bayununy, Muhammad Al-Fatah, Al Makhad ila 'ilmi Ad Dakwah, Beirut, Muassasat Ar Risalah, 1991

Al-Jurjzani, Abubakar Jabir, Minhaj al Muslim Kitab akblak Wa Ibadah Wa Muamalah, Arab Saudi, Madinah al Munawarah, 1976

Al-Usairy, Ahmad, Sejarah Islam, Sejak Zaman Nabi Adam hingga abad XX, Jakarta, Akbar Media, 2013

An Nabhani, Taqiyudin, Daulah Islam, Bogor, Pustaka Thoriqul Izzah, 2002

Arif, Mohammad, Dinamika Islamisasi Makkah \& Madinah, Asketik Vol. 2 No. 1, Juli 2018

Az Zuhaili, Wahbah, Konsep Darurat dalam Hukum Islam (Nazhariah ad Darurah as syariab), Jakarta, Gaya Media Pratama, 1997

Badri, Yatim, Sejarah Peradaban Islam (Dirasah Islamiah 2), Jakarta, PT Raja Grafindo, 2015

Darsono dan Ibrahim, Tonggak Sejarah Kebudayaan Islam 1 , Solo: Tiga Serangkai Pustaka Mandiri, 2009

Ghazali, Imam, Mukasyafatul Qulb, Surabaya: Penerbit Amelia, 2008 
Haq, Hamka, Syariat Islam, Wacana dan Penerapannya, Ujung Pandang, Yayasan al Ahkam, 2001

Hart, Michael, Seratus Tokoh Paling Berpengaruh dalam Sejarah, Jakarta, Pustaka Jaya, 1986

Hidayat, Imam, Teori-Teori Politik, Malang, Setara press, 2009

Hitti, Pilip. K, Histori of Arabs, London, Macmillan Education LTD

Ishak, Ibnu, Syarah dan Tahqiq Ibnu Hisyam Sirah Nabawi, Jakarta, Akbar Media

Ishak, Muhammad Said, Islam Keadilan Membebaskan Manusia, Malaysia, Darul Ta'zim, 2002

Ismail, A. Ilyas, Paradigma Dakwah Sayid Quthb, Jakarta, Penamadani, 2006

Jaib, Saidi, Dirosat fi Manhaj al Islami as Siyasi, Beirut, Muassisah Ar Risalah, 1985

Kafi, Jamaludin, Islam: Agama dan Negara, Surabaya, Bina Ilmu, 1983

Kanta Prawira, Rusadi, Sistem Politik Indonesia, Suatu Pengantar, Bandung, Sinar Baru 1983

Ma`arif, A. Syafi i, Islam dan Politik di Indonesia pada Masa Demokrasi Terpimpin (19591965), Yogyakarta, IAIN Sunan Kalijaga Press, 1988

Mahmud, Ahmad, Dakwah Islam, Bogor, Pustaka Toriqul Izzah, 2009

Maran, Rafael Raga, Pengantar Sosiologi Politik, Jakarta : Rieneka Cipta, 2001

Muhtadi, Asep Saeful, Dr. Era baru Politik Mubammadyah, Penerbit Humaniora, Bandung, 2005

Murdan, Hukum Islam dalam Kerangka Sistem Hukum Masyarakat Modern, Pelita, Vol 1, No. 1, April 2016

Musa, M. Yusuf, Nidzamul Hukmi Fil Islam, Cairo, 1963

Nasution, Harun, Islam Ditinjau Dari Berbagai Aspeknya, Jakarta: UI Press, 1979

Nata, Abuddin, (Ed.), Sejarah Pendidikan Islam Pada Periode Klasik dan Pertengahan Jakarta:PT RajaGrafi ndo Persada, 2010

Natsir, M., Fiqhud Dakwah, Jakarta: Dewan Dakwah Islamiah Indonesia, 1977

Noer, Deliar, Gerakan Modern Islam di Indonesia 1900-1942, Jakarta: LP3ES, Cet. Ke8, 1996

Pulungan, Suyuti, Fikih Siyasah, Ajaran, Sejarah dan Pemikiran, Jakarta, Raja Grafindo Persada, 1999 
Salim, Abdul Mu'in, Figh Siyasah: Konsepsi Kekuasaan Politik dalam AlQur'an, Jakarta: PT. RajaGrafindo, 2002

Sarwat, Ahmad, Lc, MA, Madinab era KeNabian, Jakarta; Rumah Fiqh Publishing, 2018

Soekanto, Soerjono, Sosiologi Suatu Pengantar, RadjaGrafindo Persada, Jakarta, 2002

Sofyan Ahmad, A. \& M. Roychan , Madjid, Gagasan Cak Nur, Titian Ilahi Press, Yogyakarta, 2003

Sukardja, Ahmad, Piagam Madinah dan UUD 1945, Kajian Perbandingan Tentang Hidup Bersama dalam Masyarakat yang Majemuk, Jakarta: UI press, 1995

Sukarto, Toto, dkk, Revitalisasi Pendidikan Islam, Yogyakarta, Tiara Wacana, 2006

Syalabi, A. Sejarah dan Kebudayaan Islam I, Jakarta: Pustaka al-Husna, 2003

Syukir, Asmuni, Dasar-dasar Strategi Dakwah Islam, Surabaya: al-Ikhlas, 1983

Thaba, Abd Aziz, Islam dan Negara dalam Politik Orde Baru, Jakarta, GIP, 1996

Tim Penyusun, Kamus Besar Bahasa Indonesia, Edisi III, (Jakarta: Balai Pustaka, 2005)

Ya'cub, Ali Mustafa Sejarah Dan Metode Dakwah Nabi, Jakarta, Pustaka Firdaus, 2000

Yatim, Badri, Sejarah Peradaban Islam II, Jakarta, Raja Grafindo Persada, 2015

Zahra, Muhammad Abu, Al-Dakwah ila Islam. Dar al-Fiqri al-Arabi, t.th

Zalum, Abd Qadim, Pemikiran Politik Islam, Bangil, Al Izzah, 2001

Zubaidi, Sujiat, Kritik Epistimologi dan Model Pembacaan Kontemporer, Yogyakarta, Lesfi, 2013 